GRASAS Y ACEITES, 61 (3), JULIO-SEPTIEMBRE, 279-287, 2010, ISSN: 0017-3495

DoI: $10.3989 /$ gya.112109

\title{
Elaboration process, chemical and sensory analyses of fried-salted soybean
}

\author{
By María F. Gayol ${ }^{a}$, Cecilia Riveros ${ }^{b}$ Paula Jauregui $^{a}$, Patricia R. Quiroga ${ }^{a}$, \\ Nelson R. Grosso ${ }^{b}$ and Valeria Nepote ${ }^{a^{*}}$ \\ aCTA, Facultad de Ciencias Exactas, Físicas y Naturales (UNC), \\ IMBIV-CONICET, Córdoba, Argentina. \\ ${ }^{b}$ Quimica Biológica, Facultad de Ciencias Agropecuarias (UNC), IMBIV-CONICET, \\ CC 509, 5016 Córdoba, Argentina. \\ ( ${ }^{*}$ Corresponding author: e-mail vnepote@ efn.uncor.edu)
}

\section{RESUMEN}

Proceso de elaboración y análisis químicos y sensoriales de soja frita salada.

El propósito de este trabajo fue desarrollar un proceso de elaboración de soja frita salada, determinar la composición química, la aceptabilidad por consumidores y la descripción sensorial del producto. Diferentes productos de soja frita salada fueron obtenidos bajo diferentes condiciones de temperatura y tiempo de: maceración, tostado y fritura. Los consumidores evaluaron y seleccionaron los cuatro mejores productos, los que presentaron mayor aceptación de apariencia, sabor y textura: FSS1, FSS2, FSS3, FSS4. El producto con mayor aceptación por los consumidores $(7=$ "me gusta bastante" en una escala hedónica de 9 puntos) fue FSS3, obtenido mediante maceración a $100^{\circ} \mathrm{C}$ durante 10 min y fritura a $170^{\circ} \mathrm{C}$ durante $5 \mathrm{~min}$. En este producto (FSS3) se determinó: la composición proximal y de ácidos grasos, y la intensidad de los atributos sensoriales mediante un análisis descriptivo. Las composiciones proximal y de ácidos grasos también fueron determinadas en soja cruda. FSS3 presentó menores porcentajes de humedad y de proteínas, y mayores porcentajes de lípidos e hidratos de carbono que la soja cruda. El uso de aceite de girasol en el proceso de fritura mejoró la composición de ácidos grasos del producto de soja. Los atributos sensoriales del análisis descriptivo que se detectaron con mayor intensidad en el producto de soja fueron: sabor tostado, salado, crujiente, dureza, color marrón y brillo. Este producto no es de consumo habitual y no es fácil encontrarlo disponible comercialmente. De esta manera se podría promover su consumo como un snack por su elevada calidad nutricional y sensorial.

PALABRAS CLAVES: Análisis sensorial - Composición química - Fritura - Girasol - Soja.

\section{SUMMARY}

Elaboration process, chemical and sensory analyses of fried-salted soybeans

The purpose of this work was to develop an elaboration process of fried-salted soybean and to determine the chemical composition, consumer acceptance and sensory description of the product. Different fried-salted soybean products were obtained under different temperature and time conditions by maceration in water, roasting and frying. Four of the best products were selected and evaluated by consumers (overall, color and texture acceptances): FSS1, FSS2, FSS3 and
FSS4. The product with the highest consumer acceptance (7 = "like moderately" in a hedonic scale of 9 points) was the one obtained by maceration at $100^{\circ} \mathrm{C}$ during $10 \mathrm{~min}$ and fried at $170^{\circ} \mathrm{C}$ for $5 \mathrm{~min}$ (FSS3). Proximate and fatty acid composition along with sensory attribute intensity ratings from descriptive analyses were determined on the fried-salted soybean with the highest consumer acceptance (FSS3). Proximate and fatty acid composition were also determined in raw soybeans. FSS3 had lower percentages of moisture and proteins, and higher lipids and carbohydrates than raw soybean. The use of sunflower oil in the frying process improved the fatty acid composition of the soybean product. Sensory attributes from descriptive analyses that were detected in high intensity ratings for the product were roasted, salty, crunchiness, hardness, brown color and gloss. This product is neither commonly consumed nor easily available in markets. It could be promoted to be consumed as a snack because of its high nutritional and sensory quality.

KEY-WORDS: Chemical composition - Frying - Sensory analysis - Soybean - Sunflower.

\section{INTRODUCTION}

The soybean crop is an important food source for human nutrition. Soybean products are everyday food for Asians, but are strange and sometimes hard to accept for Westerners (Golbitz, 1993).

In Argentina the grain quality is of great interest since $73 \%$ of the soybean production is exported as processed soybean meal and oil, making Argentina the world's leading exporter of these specialties (Carrera et al., 2009).

The soybean seed is a valuable commercial source of edible food and protein meal and contains approximately $42 \%$ protein and $23 \%$ oil at maturity (Dornbos and Mullen, 1992). Soybean oil is composed of about $5 \%$ to $11 \%$ linolenic, $43 \%$ to $56 \%$ linoleic, $15 \%$ to $33 \%$ oleic, and $11 \%$ to $26 \%$ saturated acids of total fatty acid composition (Collins and Sedgwick, 1959; Sipos and Szuhaj, 2001).

Soybean grains contain toxic factors such as trypsin inhibitors. Those compounds affect the availability of methionine (essential amino acid). Trypsin inhibitors could be eliminated by inactivation 
using heat treatment on raw soybeans and other legumes (Kopsic, 1985). In addition, the cooking process produces positive aroma and flavors and inactivates lipoxygenase enzyme promoting better quality and stability in the final product (KouzehKanani et al., 1981). Soybean cooking is a relatively simple process consisting of soaking the raw beans in water and cooking them for 30-120 min. This ancestral method is used extensively by local soybean producers (Mateos et al., 2002).

Roasting and deep frying are ancient food cooking processes currently used at home and in industry. The roasting treatment should be uniform in order to avoid raw or overcooked parts of the food. In contrast, the frying process gives a rapid and uniform product heating. Frying oil acts as a heat transfer medium and contributes to the texture and flavor of fried food. Fried foods have desirable flavor, color, and crispy texture which make deepfat fried foods very popular to consumers. The high temperatures used $\left(175-185^{\circ} \mathrm{C}\right)$ "seal" the surface of product, preventing a rapid loss of steam, thus facilitating the cooking of the interior and allowing the product to become more juicy. Foods fried at the optimum temperature and times have golden brown color, are properly cooked and crispy, and have optimal oil absorption.

Soybeans have high nutritional quality but they are not extensively consumed as grains. The industry uses soybeans mainly for oil extraction and protein processing. In addition, previous works on chemical and sensory analyses of fried-salted soybean products were not found. The purpose of this work was to develop an elaboration process for fried-salted soybeans and to determine the chemical composition, consumer acceptance and sensory description of the product.

\section{MATERIAL AND METHODS}

\subsection{Materials}

Sound and mature soybean seeds (crop April 20, 2007, DM 3700 variety) were obtained from Intendente Alvear, La Pampa, Argentina. Soybean seeds were inspected and damaged and bruised seeds were manually removed.

The sunflower frying oil was from Molinos Cañuelas, Cañuelas, Buenos Aires, Argentina.

\subsection{Methods}

\section{Fried-salted soybean (FSS) elaboration process}

$300 \mathrm{~g}$ of soybean seeds were macerated in $2 \mathrm{~L}$ of water at different temperatures $\left(80\right.$ y $\left.100^{\circ} \mathrm{C}\right)$ and times $(5,10,20$ and 30 minutes) in a thermostatically regulated bath (Dalvo, BMK2 model, Industria Argentina). After that, soybean seeds were roasted at different temperatures $\left(120,170\right.$ and $\left.210^{\circ} \mathrm{C}\right)$, for different time periods $(0,5,10,15,20,25$ and 30 minutes) in an oven with air circulation (Memert, modell 600 , Schwabach, Germany). Roasted seeds were fried in $1 \mathrm{~L}$ of sunflower oil at $170^{\circ} \mathrm{C}$ for different time periods (2, 3, 4, 5, 6, 10 and 15 minutes) in a fryer ("Moulinex" Principle, F30-A Series model, China). Finally, fried products were salted with $2 \%$ sodium chloride.

A total of 1064 fried soybean products were obtained from the combination of the different elaboration conditions. Four of the best products were preselected: FSS1, FSS2, FSS3 and FSS4. The elaboration conditions of these 4 products are presented in the Results and Discussion section. The selection criteria were moisture range and sensory characteristics. The Official State Bulletin from Spain (BOE, 1989) indicates that the maximum moisture content allowed in snacks is $3 \%(\mathrm{w} / \mathrm{w})$. The sensory attributes used to select the best fried soybean products were defined and evaluated by a panel trained in descriptive analysis of fried-salted soybeans according to the methodology described above in the "Sensory descriptive analysis" section. The panelists had previous experience in the descriptive analysis of peanuts products (Nepote et al., 2008, 2009; Olmedo et al., 2009; Riveros et al, 2009). The selected products (FSS1, FSS2, FSS3 and FSS4) presented the following attribute intensity ratings: brown color $50-75$, gloss $75-85$, roasted $50-$ 60 , oxidized $0-5$, cardboard $0-6$, raw/beany $0-10$, astringency $10-20$, sweet $9-15$, salty $70-90$, sour 0-7, bitter 5-15, crunchiness 60-80, hardness 50 70. After this selection those products (FSS1, FSS2, FSS3 and FSS4) were evaluated by consumers.

\section{Consumer test}

Acceptance by consumers was evaluated in the four selected fried-salted soybean products (FSS1, FSS2, FSS3 and FSS4) and in a commercial fried soybean sample (SN) (produced in Villa Martelli, Buenos Aires, Argentina) for comparison.

Panelists ( $n=100$ ) were from Córdoba (Argentina) and were recruited according to the following criteria: a) people between the ages of 18 and $65, b$ ) non-smokers, c) people without food allergies and d) people who consumed soybean and/or soybean products at least once a week. For sample evaluation, $10 \mathrm{~g}$ of soybean samples were placed into plastic cups with lids coded with 3 digit random numbers. Samples consisting of fried-salted soybeans (FSS1, FSS2, FSS3, FSS4) and commercial fried soybeans (SN) (3 replicates of each one) were prepared for each panelist. Samples were presented to panelists in random order with water and paper ballots on a plastic tray. Panelists were instructed to consume the whole sample and rinse their mouths with water between samples to minimize any residual effect. A 9-point hedonic scale ranging from 1 = "dislike extremely" to 9 = "like extremely" was used to evaluate overall acceptance of the samples (Peryam and Pilgrim, 1957).

\section{Chemical analysis}

Proximate composition of raw and fried-salted soybeans. Moisture, lipids, proteins and ashes were 
analyzed according to AOAC methods (1980) in raw soybeans (RS) and in the fried-salted soybeans with the highest consumer acceptance (FSS3). The nitrogen content was converted to protein percentage using the factor 6.25. Carbohydrate content was estimated by difference of the other components using the following formula: carbohydrate content $(\mathrm{g} \mathrm{kg}-1)=1000-($ moisture + proteins + lipids + ashes).

Fatty acid composition of sunflower oil, raw and fried-salted soybeans. Fatty acid methyl esters were obtained from the oils of the samples: sunflower oil (used to fry soybeans) (SO), raw soybeans (RS), and fried-salted soybeans (FSS3) by trans-methylation with a solution of $3 \%$ sulphuric acid in methanol, as previously described (Jellum and Worthington, 1966; Grosso et al., 2000). The fatty acid methyl esters of total lipids were analyzed on a Hewlett Packard HP-6890 gas-liquid chromatograph (Palo Alto, CA, USA) equipped with a flame ionization detector (FID HP-3398). An HP-INNO-Wax capillary column $(30 \mathrm{~m} \times 0.32 \mathrm{~mm} \times 0.5 \mathrm{~nm}$, Palo Alto, CA, USA) was used. Column temperature was programmed from $200^{\circ} \mathrm{C}$ (held for $1 \mathrm{~min}$ ) to $230^{\circ} \mathrm{C}$ $\left(20^{\circ} \mathrm{C} \mathrm{min}-1\right)$. The separated fatty acid methyl esters were identified by comparing their retention times with those of authentic samples which were purchased from Sigma Chemical Co. Quantitative fatty acid analysis was performed using heptadecanoic acid methyl ester (Sigma Chemical Co, St. Louis, MI, USA.) as internal standard. lodine values (IV) were calculated from fatty acid composition (Carreras et al., 1989) using the following formula: IV $=(\%$ oleic $\times 0.8999)+(\%$ linoleic $\times 1.814)+(\%$ linolenic $\times 2.737)$.

\section{Sensory descriptive analysis}

Trained panel. A total of 12 trained panelists (9 female and 2 male) participated in the descriptive analysis of fried-salted soybeans. All panelists were selected on the following criteria (Plemmons and Resurreccion, 1998): natural dentition, no food allergies, non-smokers, between the ages of 18-64, consume roasted soybeans and/or soybean products at least once a month, available for all sessions, interest in participating, and able to verbally communicate regarding the product. All panelists had to have a perfect score in a taste sensitivity test and the ability to identify 5 of 7 commonly found food flavors before they qualified as panelists.

Training. All 12 panelists were trained and calibrated in 4 training sessions over 4 days. Each training session lasted $2 \mathrm{~h}$ for a total of $8 \mathrm{~h}$. Descriptive analysis test procedures as described by Grosso and Resurreccion (2002) were used to train the panelists. On the first day of training, panelist were given a review of concepts of sensory analysis. Then, they were asked to taste standard solutions of sucrose, sodium chloride, citric acid, and caffeine at varying concentrations and intensities that corresponded to points on a $150 \mathrm{~mm}$ unstructured line scale (Plemmons and Resurreccion, 1998). After that, all 12 panelists worked together to develop the language to describe perceivable product attributes in FSS. Fresh samples of FSS were presented to each panelist. Panelists identified appearance, aromatics, taste and texture attributes that would be used to describe the product samples. A lexicon for peanut samples (Johnsen et al., 1988) was used to provide an initial list of attributes. Panelists decided whether terms were redundant and should be removed or if additional terms should be included in the list of attributes and defined each attribute (Table 1). Panelists also identified references to be used to describe each appearance, flavor, and texture attribute. Each panelist gave an intensity rating for each reference between 0 and 150 for each attribute. The mean intensity rating was calculated and used as attribute in intensity rating for that particular reference (Table 1).

On the second day of training, panelists reviewed descriptors, definitions, and reference standards to describe FSS samples. Panelists tasted each reference and provided a rating. The panel was calibrated by obtaining an average panel rating with a standard deviation within 10 points. Panelists not rating within \pm 10 points of the mean rating were asked to re-evaluate the sample and adjust their rating until a consensus was reached. After that, medium fired- salted soybeans were presented as a warm-up sample to be used for each panelist as the initial sample during training and testing sessions (Plemmons and Resurreccion, 1998).

On the third day of training, panelists finalized the definitions, descriptors, and reference standard intensities to describe FSS. Then, the list of definitions (Table 1) and warm-up and reference intensity ratings were finalized. After that, panelists evaluated 4 FSS fresh sample flavors using paper ballots in order to calibrate themselves.

On the last day of training, panelists continued evaluating FSS samples with different degrees of roasted and oxidized flavors to practice and to calibrate themselves within \pm 10 points of the mean ratings for each attribute of the samples.

Sample evaluation. All samples were evaluated in partitioned booths under fluorescent light at room temperature. Ten grams of product sample were placed into plastic cups. Panelists evaluated 4 samples plus a warm-up sample. The final lists of warm-up and reference intensity ratings and definitions were posted in the booths for test sessions. Samples were tested using a complete randomized block design. The data were registered on paper ballots.

\section{Statistical Analysis}

The experiment was repeated 3 times. The data were analyzed using the InfoStat software, version 2008p (Facultad de Ciencias Agropecuarias, Universidad Nacional de Córdoba). Means and standard deviations were calculated. Analysis of 
Table 1

Definitions of attributes, standard references, and warm-up intensity ratings used in a descriptive analysis of fried-salted soybeans (FSS3)

\begin{tabular}{|c|c|c|c|c|}
\hline Attribute $^{a}$ & Definition $^{b}$ & Reference & $\begin{array}{l}\text { Reference } \\
\text { intensity }^{c}\end{array}$ & $\begin{array}{l}\text { Warm up } \\
\text { Intensity }\end{array}$ \\
\hline \multicolumn{5}{|l|}{ Appearance } \\
\hline 1- Brown Color & $\begin{array}{l}\text { The intensity or the strength of brown } \\
\text { color from light to dark brown. }\end{array}$ & Color $4861^{\mathrm{e}}$ & 65 & 70 \\
\hline 2- Gloss & $\begin{array}{l}\text { The amount of reflected light from } \\
\text { product. }\end{array}$ & Chocolate peanuts $^{\dagger}$ & 58 & 80 \\
\hline \multicolumn{5}{|l|}{ Aromatics } \\
\hline $\begin{array}{l}\text { 3-Roasted } \\
\text { Soybeans }\end{array}$ & $\begin{array}{l}\text { The aroma associated with medium } \\
\text { roasted soybeans. }\end{array}$ & $\begin{array}{l}\text { Dry roasted peanuts (JL SA, } \\
\text { Ticino, Córdoba, Argentina) }\end{array}$ & 76 & 55 \\
\hline 4- Oxidized & $\begin{array}{l}\text { The aroma associated with rancid fats } \\
\text { and oils. }\end{array}$ & Rancid Fried Soybeans & 76 & 5 \\
\hline 5- Cardboard & $\begin{array}{l}\text { The aroma associated with wet } \\
\text { cardboard. }\end{array}$ & Moist cardboard & 41 & 5 \\
\hline 6- Raw/ Beany & $\begin{array}{l}\text { The aroma associated with uncooked } \\
\text { or raw soybeans. }\end{array}$ & Raw soybeans & 80 & 5 \\
\hline \multicolumn{5}{|c|}{ 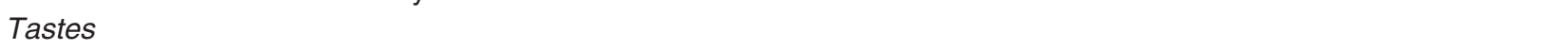 } \\
\hline & & $2.0 \%$ sucrose solution & 20 & \\
\hline 7- Sweetness & $\begin{array}{l}\text { Taste on the tongue associated with } \\
\text { sucrose solutions. }\end{array}$ & $\begin{array}{l}5.0 \% \text { sucrose solution } \\
10 \% \text { sucrose solution } \\
15 \% \text { sucrose solution }\end{array}$ & $\begin{array}{c}50 \\
100 \\
150\end{array}$ & 12 \\
\hline 8- Salty & $\begin{array}{l}\text { Taste on the tongue associated with } \\
\text { sodium chloride solutions. }\end{array}$ & $\begin{array}{l}0.2 \% \mathrm{NaCl} \text { solution } \\
0.35 \% \mathrm{NaCl} \text { solution } \\
0.5 \% \mathrm{NaCl} \text { solution }\end{array}$ & $\begin{array}{l}25 \\
50 \\
85\end{array}$ & 100 \\
\hline 9- Sour & $\begin{array}{l}\text { Taste on the tongue associated with } \\
\text { acid agents such as citric acid solutions. }\end{array}$ & $\begin{array}{l}0.05 \% \text { caffeine solution } \\
0.08 \% \text { caffeine solution } \\
0.15 \% \text { caffeine solution }\end{array}$ & $\begin{array}{c}20 \\
50 \\
100\end{array}$ & 5 \\
\hline 10-Bitter & $\begin{array}{l}\text { Taste on the tongue associated with } \\
\text { bitter solutions such as caffeine. }\end{array}$ & $\begin{array}{l}0.05 \% \text { citric acid solution } \\
0.08 \% \text { citric acid solution } \\
0.15 \% \text { citric acid solution }\end{array}$ & $\begin{array}{c}20 \\
50 \\
100\end{array}$ & 2 \\
\hline Texture & & & & \\
\hline 11- Hardness & $\begin{array}{l}\text { Force needed to compress a food } \\
\text { between molar teeth. }\end{array}$ & $\begin{array}{l}\text { Almonds (Grandiet, } \\
\text { Cordoba, Argentina) }\end{array}$ & 74 & 60 \\
\hline 12- Crunchiness & $\begin{array}{l}\text { Force needed and amount of sound } \\
\text { generated from chewing a sample with } \\
\text { molar teeth. }\end{array}$ & $\begin{array}{l}\text { Corn flakes (Granix, } \\
\text { Buenos Aires, Argentina) }\end{array}$ & 90 & 75 \\
\hline Feeling factor & & & & \\
\hline 13- Astringency & $\begin{array}{l}\text { The shrinking or puckering of the tongue } \\
\text { surface caused by sub- stances such as } \\
\text { tannins or alum. }\end{array}$ & $\begin{array}{l}\text { Tea' } \\
\text { Raw Soybeans }\end{array}$ & $\begin{array}{l}45 \\
40\end{array}$ & 15 \\
\hline
\end{tabular}

${ }^{a}$ Attributes listed in order as perceived by panelists. ${ }^{\text {b}}$ The attribute definitions were based on a lexicon for peanut samples (Muñoz et al., 1992). 'Intensity ratings are based on 150-mm unstructured line scales. "Medium roasted soybeans. ${ }^{\text {e }}$ Color Table $\mathrm{N}^{\circ} 4861$ "Alba", Argentina. ${ }^{\dagger}$ Chocolate Peanut, "Arcor", Cordoba, Argentina. ${ }^{9}$ Almonds, "Grandiet”, Cordoba, Argentina.

h Corn flakes, "Granix", Buenos Aires, Argentina. 'Tea Infusión "The Virginia", 5 bags in 1 liter water at $90^{\circ} \mathrm{C}$ for 2 hs.

variance $(\alpha=0.05)$ and Duncan test were performed to find significant differences between means from the consumer responses, proximate composition and fatty acid composition in soybean products.

\section{RESULTS AND DISCUSSION}

\subsection{Fried-salted soybean (FSS) elaboration process}

Elaboration conditions and moisture contents of the four preselected soybean products are presented in Table 2. Products FSS1 and FSS4 were elaborated by maceration, roasting and frying, while products FSS2 and FSS3 were obtained by a shorter process of maceration and frying, without roasting. All products were processed at temperatures and times required to deactivate the soybean's antinutritional factors. Mateos et al. (2002) found that antinutritional factors are deactivated by short treatments at high temperatures $\left(130\right.$ to $170^{\circ} \mathrm{C}$ for 10 to $180 \mathrm{sec}$.) or by long processes at a low temperature (maximum temperature $105^{\circ} \mathrm{C}$ for 15 to $30 \mathrm{~min}$ ). 
Table 2

Elaboration conditions and moisture content of fried soybean products selected prior to the consumer analysis

\begin{tabular}{|c|c|c|c|c|c|c|c|}
\hline \multicolumn{8}{|c|}{ Processes } \\
\hline \multirow[b]{2}{*}{ Products $^{f}$} & \multicolumn{2}{|c|}{ Maceration } & \multicolumn{2}{|c|}{ Roasting } & \multicolumn{2}{|c|}{ Frying } & \multirow{2}{*}{$\begin{array}{c}\text { Moisture } \\
\text { percentage }^{g}\end{array}$} \\
\hline & $\begin{array}{c}\text { Temperature } \\
\left({ }^{\circ} \mathrm{C}\right)\end{array}$ & $\begin{array}{l}\text { Time } \\
(\mathrm{min})\end{array}$ & $\begin{array}{c}\text { Temperature } \\
\left({ }^{\circ} \mathrm{C}\right)\end{array}$ & $\begin{array}{l}\text { Time } \\
(\mathrm{min})\end{array}$ & $\begin{array}{c}\text { Temperature } \\
\text { (C) }\end{array}$ & $\begin{array}{l}\text { Time } \\
(\min )\end{array}$ & \\
\hline FSS1 & 100 & 10 & 170 & 20 & 170 & 2 & $2.29^{d}$ \\
\hline FSS2 & 80 & 10 & - & - & 170 & 6 & $3.06^{\mathrm{e}}$ \\
\hline FSS3 & 100 & 10 & - & - & 170 & 5 & $1.73^{b}$ \\
\hline FSS4 & 80 & 10 & 120 & 30 & 170 & 3 & $1.00^{\mathrm{a}}$ \\
\hline SN & & & & & & & $2.08^{c}$ \\
\hline
\end{tabular}

${ }^{\dagger}$ FSS: Fried-salted soybean products selected prior to the consumer analysis. SN: commercial fried-salted soybean product. ${ }^{9}$ Different letters in the same column indicate significant differences among samples $(\alpha=0.05)$.

All products presented moisture between 1.00 to $3.06 \mathrm{~g} / 100 \mathrm{~g}$ and better attributes of appearance, flavor and texture according to the evaluation by the trained panel. The soybean products presented significant differences in moisture content. The products with the highest and the lowest moisture contents were FSS2 (3.06 \%) and FSS4 (1.00\%), respectively. The maximum moisture content allowed in snacks is $3 \%$ (BOE, 1989). In addition, when moisture was lower than $1 \%$ the product exhibited burnt flavor, dark color and was easily cracked. According to this trained panel, maceration time (10, 20 and $30 \mathrm{~min})$ did not affect the final product's sensory characteristics; therefore, the shortest maceration time (10 minutes) was chosen.

\subsection{Consumer test}

The averages of overall, texture and color acceptance of the products from consumer tests are shown in Figure 1. Soybean products presented significant differences in those variables. FSS1 and FSS3 showed higher averages for overall and texture acceptance (close to 7, "I like moderately" in the hedonic scale of 9 points) than the other products. FSS1 and FSS3 did not significantly differ in those variables. FSS3 presented significant differences in comparison with the products FSS2, FSS4 and SN. FSS1 only presented significant differences in comparison with $\mathrm{SN}$ in overall and texture acceptance. In addition, the products FSS1, FSS2 and FSS3 presented higher averages for color acceptance (close to 7, "I like moderately", without significant differences among them) than the products FSS4 and SN. The commercial product SN showed the lowest values for all analyzed variables (close to 5, "neither like nor dislike") with significant differences compared to the other products.

Grosso and Resurrection (2002) found overall acceptance between 6.1 and 6.4 in a hedonic scale

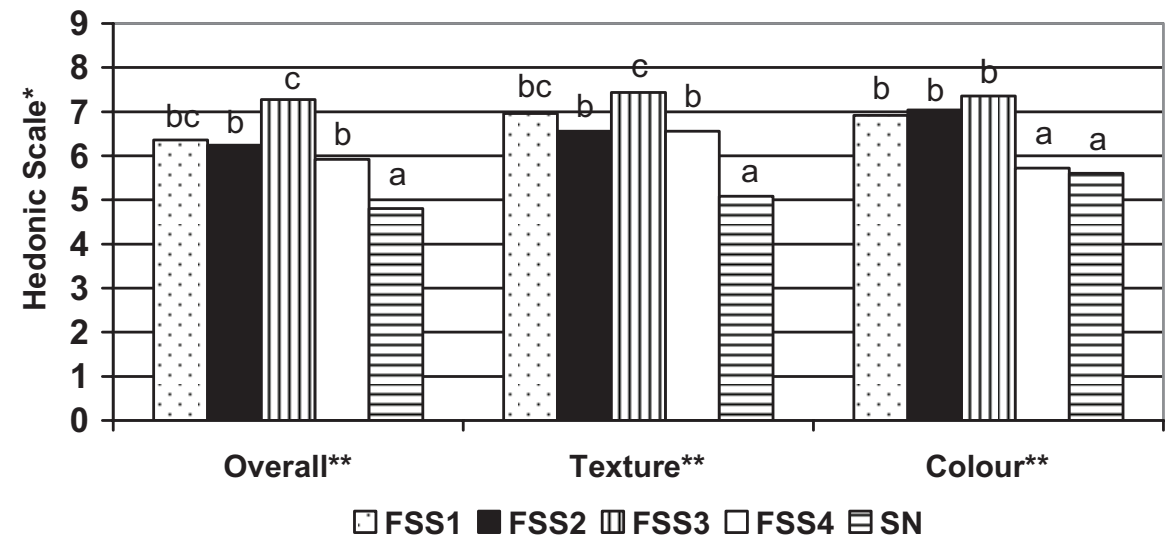

Figure 1

Average of overall, texture and color acceptance from consumer test in the different fried-salted soybean products: FSS1, FSS2, FSS3, FSS4 and commercial product SN. *Hedonic scale: 1 . Dislike extremely; 2 . Dislike very much; 3. Dislike moderately; 4 . Dislike slightly; 5 . Neither like nor dislike; 6 . Like slightly; 7. Like moderately; 8 . Like very much; 9. Like extremely. ${ }^{*}$ Different letters in the bars indicate significant differences among samples (ANOVA and LSD test, $\alpha=0.05$ ). 
of 9 points for cracker-coated peanuts. Nepote et al. (2004) reported overall acceptance of about 6 (in a hedonic scale of 9 points) for honey roasted peanuts.

\subsection{Proximate composition on raw soybean and fried-salted soybean}

The moisture, protein, lipid, total carbohydrate and ash percentages in raw soybeans and in fried-salted soybeans (FSS3) are presented in Table 3. FSS3 showed higher lipid and carbohydrate, and lower moisture and protein percentages than RS. According to these results, after the frying process, moisture decreased and lipids increased in the product. A decrease in moisture could imply increases in other components (lipids, proteins, ash and carbohydrates). On the other hand, oil absorption during the frying process implied an increase in lipids and a decrease in the other components (protein, carbohydrates and ash). However, oil absorption was lower than moisture loss in this product. In addition, the high temperature of the frying process could cause protein denaturing and loss of nitrogen. That could be an explanation for the significant decrease in proteins and the relative increase in carbohydrates. Other authors found total nitrogen and protein decrease in other fried foods (Ponnampalam and Mondy, 1983; Shiau and Shue, 1989). Significant differences between RS and SFF3 were not detected in ash content.

Kawamura (1967) reported $40 \%$ proteins, $21 \%$ oil and $34 \%$ carbohydrates in soybean seeds. LamSanchez and Dutra de Oliveira (1973) reported that the protein and oil percentages in soybeans from Sao Paulo (Brazil) ranged from 31.8 to $38 \%$ and 17.2 to $25.9 \%$ on a dry basis, respectively. In the germplasm collection of the Department of Agriculture (USDA), a wide range in these characteristics exists, ranging from 36.6 to $50 \%$ protein (Hartwig, 1979) and from 13.2 to $23.5 \%$ oil (Wilcox, 1985).

In the present work, it can be observed that while lipid content in the soybean products increased, protein content decreased. Similar results were reported by Fehr (1987) and Burton (1985). Those authors found a negative correlation between protein and oil in soybeans, with absolute values greater than 0.50 .

\subsection{Fatty acid composition of sunflower oil, raw soybean and fried-salted soybean products.}

The fatty acid percentages of the sunflower oil (SO) used to fry the soybeans, raw soybeans (RS) and fried-salted soybeans (FSS3) are presented in Table 4 . The main fatty acids found in all samples were oleic acid (18:1 n-9), linoleic acid (18:2 n-6) and palmitic acid (16:0). Palmitic (16:0) and stearic (18:0) acids were the most prominent of the saturated acids, and oleic (18:1) and linoleic (18:2) acids were the most prominent of the unsaturated fatty acids in all samples. Significant differences were found between samples in most of the fatty acids percentages. SO presented the highest amount of oleic acid (38.32\%) followed by the product FSS3 (28.75\%) and finally by RS $(21.13 \%)$, with significant differences. RS showed the highest content of linoleic and linolenic acids $(57.15 \%$ and $8.86 \%$, respectively) followed by SFF3 $(55.43 \%$ and $2.53 \%$, respectively) and finally by SO (51.14 $\%$ and traces, respectively). Linoleic and linolenic fatty acids are susceptible to oxidation, therefore the greater the amount of these acids the greater the susceptibility of the sample to lipid oxidation (St. Angelo, 1996).

SO had the highest $\mathrm{O} / \mathrm{L}$ ratio $(0.75)$, followed by FSS3 (0.52) and finally by RS (0.37). A higher $\mathrm{O} / \mathrm{L}$ ratio implies higher lipid stability (Nepote et al., 2006).

RS showed a higher S/U ratio (0.30) than the other samples. This was mainly due to the higher amount of palmitic acid and the lower content of oleic acid in RS in comparison with FSS3 and SO.

lodine value (IV) is a direct measure of the unsaturation degree and instability of lipids. The Argentine Food Code (CAA, 1969) stipulates that sunflower oil should have an IV between 119 and 138. In the present work IV in SO was in that range (123.03) and it was significantly lower than in FSS3 (128.78) and in RS (142.24). FSS3 and RS also showed significant differences in their IV.

These results indicate that raw soybeans changed their fatty acid contents after the frying process in sunflower oil. This could be due to the partial absorption of the sunflower oil into the soybean product (Nepote et al., 2006). After the frying of soybeans, palmitic, linoleic and linolenic acids decreased while oleic acid increased. In addition, IV and S/U decreased, and O/L increased in the fried product (FSS3). Consequently, soybeans fried in sunflower oil could be more stable to lipid oxidation than soybeans roasted without frying.

Previous works on fried peanuts reported changes in chemical and fatty acid compositions due to the frying process in sunflower oil (Bolton and Sanders, 2002; Nepote et al., 2006).

Table 3

Proximate composition (\% w/w on dry basis) of raw soybean (RS) and fried-salted soybean (FSS3)

\begin{tabular}{lccccc}
\hline Sample & Moisture $^{c}$ & Lipids $^{c}$ & Proteins $^{c}$ & Ashes $^{c}$ & Carbohydrates $^{c}$ \\
\hline RS & $9,49 \pm 0.10 \mathrm{~b}$ & $16,66 \pm 1.51 \mathrm{a}$ & $42,69 \pm 0.46 \mathrm{~b}$ & $4,79 \pm 0.27$ & $26,36 \pm 1,61 \mathrm{a}$ \\
FSS3 & $1,5 \pm 0.17 \mathrm{a}$ & $23,37 \pm 0.20 \mathrm{~b}$ & $39,03 \pm 0.56 \mathrm{a}$ & $4,83 \pm 0.28$ & $31,27 \pm 0.68 \mathrm{~b}$ \\
\hline
\end{tabular}

${ }^{c}$ Mean \pm Standard Deviation $(n=3)$. Different letters in the same column indicate significant differences among samples $(\alpha=0.05)$. 
Table 4

Fatty acid composition ( $n=3$ ) of sunflower oil (SO), raw soybean (RS) and fried-salted soybean (FSS3)

\begin{tabular}{|c|c|c|c|c|c|c|c|c|c|c|}
\hline \multirow{3}{*}{ Fatty Acids } & \multicolumn{10}{|c|}{ Composition (g/100g fatty acids) } \\
\hline & \multicolumn{4}{|c|}{ so } & \multicolumn{3}{|c|}{ RS } & \multicolumn{3}{|c|}{ FSS3 } \\
\hline & & Mean & SD & d & Mean & SD & d & Mean & SD & d \\
\hline \multicolumn{11}{|l|}{ Saturated } \\
\hline Palmitic acid & C16:0 & 5,88 & 0,17 & a & 9,60 & 0,23 & C & 6,91 & 0,17 & $\mathrm{~b}$ \\
\hline Stearic acid & C18:0 & 2,85 & 0,05 & & 3,26 & 0,49 & & 3,33 & 0,14 & \\
\hline Arachidic acid & C20:0 & 0,23 & 0,01 & & 0,30 & 0,10 & & 0,39 & 0,08 & \\
\hline Behenic acid & C22:0 & 0,66 & 0,03 & $\mathrm{~b}$ & 0,30 & 0,10 & $\mathrm{a}$ & 0,48 & 0,08 & $a b$ \\
\hline Lignoceric acid & $\mathrm{C} 24: 0$ & 0,27 & 0,00 & $\mathrm{~b}$ & $\operatorname{tr}$ & & $\mathrm{a}$ & 0,21 & 0,00 & $\mathrm{~b}$ \\
\hline Total & & 9,89 & 0,08 & a & 26,32 & 0,72 & $\mathrm{~b}$ & 11,25 & 0,57 & $\mathrm{a}$ \\
\hline \multicolumn{11}{|l|}{ Monounsaturated } \\
\hline Palmitoleic acid & C16:1 & 0,60 & 0,00 & c & $\operatorname{tr}$ & & $\mathrm{a}$ & 0,18 & 0,00 & $\mathrm{~b}$ \\
\hline Oleic acid & C18:1 & 38,32 & 0,50 & C & 21,13 & 0,21 & a & 28,75 & 0,42 & $\mathrm{~b}$ \\
\hline Eicosenoic acid & C20:1 & 0,26 & 0,05 & $\mathrm{~b}$ & 0,10 & 0,01 & $\mathrm{a}$ & 0,26 & 0,03 & $\mathrm{~b}$ \\
\hline Total & & 38,87 & 0,03 & $\mathrm{C}$ & 21,23 & 0,21 & $\mathrm{a}$ & 29,06 & 0,53 & $\mathrm{~b}$ \\
\hline \multicolumn{11}{|l|}{ Polyunsaturated } \\
\hline Linoleic acid & C18:2 & 51,14 & 0,18 & a & 57,15 & 0,64 & C & 55,43 & 0,32 & $b$ \\
\hline Linolenic acid & C18:3 & $\operatorname{tr}$ & & $\mathrm{a}$ & 8,86 & 0,20 & $\mathrm{C}$ & 2,53 & 0,02 & $\mathrm{~b}$ \\
\hline Total & & 51,14 & 0,18 & $\mathrm{e}$ & 66,01 & 0,84 & $\mathrm{C}$ & 57,96 & 0,34 & $\mathrm{~b}$ \\
\hline Oleic/Linoleic ratio & $\mathrm{O} / \mathrm{L}$ & 0,75 & 0,01 & C & 0,37 & 0,04 & a & 0,52 & 0,01 & $\mathrm{~b}$ \\
\hline lodine Value ${ }^{e}$ & IV & 123,03 & 0,09 & a & 142,24 & 0,08 & C & 128,78 & 0,93 & $\mathrm{~b}$ \\
\hline Saturated/Unsaturated ratio & $S / U$ & 0,11 & 0,00 & a & 0,30 & 0,02 & $\mathrm{~b}$ & 0,13 & 0,01 & $\mathrm{a}$ \\
\hline
\end{tabular}

tr: trace value $(<0,03 \mathrm{~g} / 100 \mathrm{~g}) .{ }^{\mathrm{d}}$ Different letters in each row indicate significant differences among samples $(\alpha=0.05)$. ${ }^{\mathrm{e}} \mathrm{IV}$ : iodine value $=\left(\% \mathrm{C} 18: 1^{*} 0,899\right)+(\% \mathrm{C} 18: 2 * 1,814)+(\% \mathrm{C} 18: 3 * 2,737)$

\subsection{Descriptive analysis of fried-salted soybeans}

Intensity ratings of sensory attributes from the descriptive analysis of fried-salted soybeans (FSS3) are presented in Figure 2. The attributes detected by panelists at intensity ratings higher than 50 (in a $0-150 \mathrm{~mm}$ scale) were: brown color and gloss for appearance, hardness and crunchiness for texture, and roasted and salty for flavor. The other attributes were found in low intensity ratings (less

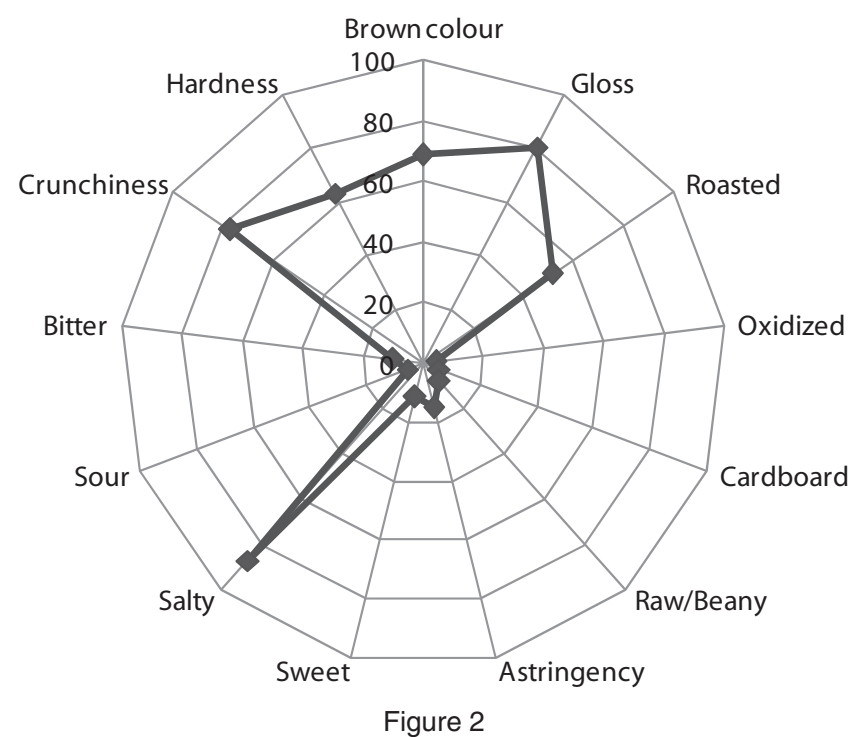

Attribute intensity ratings (scale $0-150 \mathrm{~mm}$ ) from the descriptive analysis of fried-salted soybeans (FSS3). 
than 15). Previous research on sensory attributes of soybean products from descriptive analyses have not been found. However, previous works on fried salted peanuts reported intensity ratings of sensory attributes from descriptive analyses (Olmedo et al., 2009). Fried salted soybeans showed lower intensity ratings for roasted soybeans, oxidized, cardboard, sweet and bitter, and higher intensity ratings for brown color, gloss, salty, sour, crunchiness and hardness than fried salted peanuts. Other results from sensory descriptive analyses on peanut products from Argentina were presented by Riveros et al (2009) and Nepote et al (2008). Those authors found intensity ratings for roasted peanutty of 57.1 and 51.4 in peanut paste and roasted peanuts, respectively. Grosso and Resurreccion (2002) found intensity ratings for roasted peanutty of 67 and 63 in roasted peanuts and cracker coated peanuts from USA, respectively.

\section{CONCLUSIONS}

The fried salted soybean product that presented the best consumer acceptance was FSS3. This product was prepared at laboratory scale by maceration at $100^{\circ} \mathrm{C}$ for 10 minutes, and then fried at $170^{\circ} \mathrm{C}$ for 5 minutes in sunflower oil. The frying process caused changes in the chemical and fatty acid compositions of this soybean product. The final product (FSS3) had lower percentages of moisture and proteins, and higher lipids and carbohydrates than raw soybeans. The use of sunflower oil in the frying process improved the fatty acid composition of the soybean product. The final product presented a higher oleic/linoleic ratio, and lower iodine value and saturated/unsaturated ratio than raw soybeans. Sensory attributes from descriptive analyses that were detected in high intensity ratings in fried-salted soybeans were roasted, salty, crunchiness, hardness, brown color and gloss. This product is neither commonly consumed nor easily available in markets. It could be promoted to be consumed as a snack because of its high nutritional and sensory quality.

\section{ACKNOWLEDGEMENTS}

This work was supported by CONICET, Agencia Córdoba Ciencia and SECYT-UNC.

\section{REFERENCES}

AOAC. 1980. Official Methods of Analysis. Horwitz W (Ed.), 13th ed, Association of Official Analytical Chemists, Washington, DC, USA, pp. 435-440.

BOE (Boletín Oficial del Estado). 1989. Real Decreto 126 , por el que se aprueba la reglamentación técnicosanitaria para elaboración y comercialización de patatas fritas y productos de aperitivo. Valladolid, España.

Bolton GE, Sanders TH. 2002. Effect of roasting oil composition on the stability of roasted high-oleic peanuts. JAOCS 79, 129-132.

Burton JW. 1985. Breeding soybeans for improved protein quantity and quality. In: Proceedings of World Soybean Research Conference III. Shibles R., ed. Ames. lowa. EE.UU, pp. 361-367.
Carreras ME, Fuentes E, Guzmán CA. 1989. Chemotaxonomy of seed lipids of Cucurbitaceae grown in Argentina. Biochem. Syst. Ecol. 17, 287-291.

Carrera C, Martinez MJ, Dardanelli J, Balzarini M. 2009. Water deficit effect on the relationship between temperature during the seed fill period and soybean seed oil and protein concentrations. Crop Science 49, 1-9.

Código Alimentario Argentino (CAA). 1969. Ley 18284. Capítulo XI: Alimentos Vegetales y Capítulo VII: Alimentos Grasos. Ministerio de Salud y Acción Social. Argentina.

Collins FI, Sedgwick VE. 1959. Fatty Acid Composition of Several Varieties of Soybeans. JAOCS 36, 641- 644.

Dornbos DL, Mullen RE. 1992. Soybean Seed Protein and Oil Contents and Fatty Acid Composition Adjustments by Drought and Temperature. JAOCS 69, 228- 231.

Fehr WR. 1987. Breedings methods for cultivar development. In: Soybeans: improvement, production and uses. JR. Wilcox (Ed), 2 ed, Agron. Mono 16 Madison, WI, EE UU. American Society of Agronomy, pp. 249 - 293.

Golbitz P. 1993. Aspectos prácticos de la comercialización de productos de soja listos para su consumo. Soya Noticias 227, 6-13.

Grosso NR, Nepote V, Guzman CA. 2000. Chemical composition of some wild peanut species (Arachis L.) seeds. J. Agric. Food Chem. 48, 806-809.

Grosso NR, Resurreccion AVA. 2002. Predicting consumer acceptance ratings of cracker-coated and roasted peanuts from descriptive analysis and hexanal measurements. J. Food Sci. 67, 1530-1537.

Hartwig EE. 1979. Breeding productive soybeans with higher percentage of protein. Seed protein improvement in cereals and grain legumes. Int. Atomic Energy Agency 2, 59-66.

Jellum MD, Worthington RE. 1966. A rapid method of fatty acid analysis of oil from individual corn (Zeamays L.) kernels. Crop Science 6, 251-253.

Johnsen PB, Civille GV, Vercellotti JR, Sanders TH, Dus CA. 1988. Development of a lexicon for the description of peanut flavor. J. Sensory Studies 3, 9-17.

Kawamura S. 1967. A review on the chemistry of soybean polysaccharides. Nippon Shokuhin Kogyo Gakkaishi 14, 514-523,553-562.

Kopsic T. 1985. Propiedades de la soja. Universidad Nacional del Sur. Bahìa Blanca. Argentina.

Kouzeh-Kanani M, van Zuilichem DJ, Roozen JP, Pilnik W. 1981. A modified procedure for low temperature infrared radiation of soybean. Lebensmittel Wisscheschaft Und Technologie 14, 242-244.

Lam- Sánchez A, Dutra de Oliveira JE. 1973. Protein and oil content in several soybean varieties.

Mateos GG, Latorre MA, Lázaro R. 2002. Procesamiento del haba de soja. Departamento de Producción Animal, UP Madrid. ASA.

Nepote V, Mestrallet MG, Grosso NR. 2004. Natural antioxidant effect frompeanut skins in honey roasted peanuts. J. Food Sci. 69, 295-300.

Nepote V, Mestrallet MG, Grosso NR. 2006. Oxidative stability in fried-salted peanuts elaborated with higholeic and regular peanuts from Argentina. Int. J. Food Sci. Tech. 41, 900-909.

Nepote V, Mestrallet MG, Olmedo RH, Ryan LC, Conci S, Grosso NR. 2008. Chemical composition and sensory analysis of roasted peanuts coated with prickly pear and algarrobo pod syrups. Grasas y Aceites 59, 174-181. 
Nepote V, Olmedo RH, Mestrallet MG, Grosso NR. 2009. A Study of the Relationships among Consumer Acceptance, Oxidation Chemical Indicators, and Sensory Attributes in High-Oleic and Normal Peanuts. J. Food Sci. 74, S1-S8.

Olmedo RH, Asensio C, Nepote V, Mestrallet MG, Grosso NR. 2009. Chemical and sensory stability of fried-salted peanuts flavored with oregano essential oil and olive oil. J. Sci. Food Agric. 89, 2128-2136.

Peryam DR, Pilgrim FJ. 1957. Hedonic scale method of measuring food preferences. Food Technol. 11, 9-14.

Plemmons LE, Resurreccion AVA. 1998. A WarmUp Sample improves reliability of responses in descriptive analysis. J. Sensory Studies 13, 359-376.

Ponnampalam R, Mondy NI. 1983. Effect of Baking and Frying on Nutritive Value of Potatoes. Nitrogenous Constituents. J. Food Sci. 48, 1613-1616.

Riveros CG, Mestrallet MG, Nepote V, Grosso NR. 2009. Chemical composition and sensory analysis of peanut pastes elaborated with high-oleic and regular peanuts from Argentina. Grasas y Aceites 60, 388-395.

Sipos EF, Szuhaj BF. 2001. Aceite de soja: composición y propiedades físicas. Aceites y Grasas. Libro $10^{\circ}$ Aniversario. Tomo I, pp. 52- 58.

Shiau S-Y, Shue M-J. 1989. Effects of Prefrying Times on the Nutritive Value of Canned Tilapia Meat. J. Agric. Food Chem. 37, 385-388.

St. Angelo AJ. 1996. Lipid oxidation in food. Critical Reviews in Food Science and Nutrition 36, 175-224.

Wilcox JR. 1985. Breeding soybeans for improved oil quantity and quality. In: Proceedings of World Soybean Research Conference III. Shibles, R, ed. Ames. lowa. EE.UU, pp. 380-386. 